\title{
Aklimatisasi dan Respon Pertumbuhan Mutan Leucaena leucocephala Varietas Tarramba Teradaptasi Asam
}

Acclimatization and Growth Respond of The Acid-Adapted Mutant of Leucaena leucocephala cv. Tarramba

Muhklisani*, P D M H Karti, I Prihantoro

Corresponding email:

lisamuhklisani@apps.ipb.ac.id

Departemen Ilmu Nutrisi dan Teknologi Pakan Fakultas Peternakan IPB University, Jl. Agatis Kampus IPB Dramaga, Bogor, Indonesia

Submitted: 14 $4^{\text {th }}$ August 2021 Accepted : $5^{\text {th }}$ November 2021

\section{ABSTRACT}

Acclimatization is the final stage of plant propagation in tissue culture techniques that can determine the success of the nursery process. This study aimed to observe the growth response during the acclimatization stage of the acid-adapted of Leucaena leucocephala Tarramba variety, which developed from tissue culture techniques. The design used in this study was a completely randomized design (CRD) with the cultivation of 11 mutant lines from tissue culture, namely M1-M11 (an acid-adapted mutant from tissue culture addition of 1 ppm IBA) and 2 controls (lamtoro broodstock without gamma irradiation) namely K0 (lamtoro broodstock resulting from tissue culture addition of 0 ppm IBA), K1 (breeding lamtoro from tissue culture addition of 1 ppm IBA). The variables observed were the level of plant viability, plant height, and number of leaves. The results showed that the acclimatization of the plant Leucaena leucocephala to tissue culture production on the M3 and M9 mutant lines gave the best response to plant morphological growth up to 5 WAP (weeks after planting).

Key words: acclimatization, IBA hormone, Leucaena leucocephala, tissue culture

\section{ABSTRAK}

Aklimatisasi merupakan tahapan akhir dari perbanyakan tanaman pada teknik kultur jaringan yang dapat menentukan keberhasilan proses pembibitan. Penelitian ini bertujuan untuk melihat respon pertumbuhan selama tahap aklimatisasi pada tanaman Leucaena leucocephala varietas Tarramba toleran asam yang dikembangkan dari hasil teknik kultur jaringan. Rancangan yang digunakan pada penelitian ini yaitu Rancangan Acak Lengkap (RAL) dengan penanaman 11 galur mutan hasil kultur jaringan yaitu M1M11 (mutan toleran asam hasil kultur jaringan penambahan 1 ppm IBA), dan 2 kontrol (lamtoro indukan tanpa penyinaran gamma) yaitu K0 (lamtoro indukan hasil kultur jaringan penambahan 0 ppm IBA), K1 (lamtoro indukan hasil kultur jaringan penambahan 1 ppm IBA). Variabel yang diamati yaitu tingkat viabilitas tanaman, tinggi tanaman dan jumlah daun. Hasil penelitian menunjukkan bahwa aklimatisasi tanaman Leucaena leucocephala produksi kultur jaringan pada galur mutan M3 dan M9 memberikan respon terbaik terhadap pertumbuhan morfologi tanaman hingga 5 MST (minggu setelah tanam).

Kata kunci: aklimatisasi, hormone IBA, kultur jaringan, Leucaena leucocephala 


\section{PENDAHULUAN}

Hijauan pakan merupakan sumber pakan utama dengan kandungan nutrien yang baik bagi ternak ruminansia. Salah satu jenis leguminosa yang sudah dikenal oleh peternak adalah lamtoro (Leucaena leucocephala). Tanaman lamtoro memiliki kandungan protein kasar sebesar $15 \%$ - 38\% dengan palatabilitas yang tinggi (Zayed et al. 2014). Lamtoro varietas Tarramba merupakan salah satu jenis lamtoro yang sudah lama dikembangkan di Indonesia. Keunggulan dari jenis varietas ini adalah mampu tumbuh pada kondisi tanah kering dan tahan terhadap hama kutu loncat, akan tetapi belum diketahui pasti tumbuh baik pada lahan masam di Indonesia (Manpaki et al. 2017).

Perbaikan genetik tanaman yang unggul dan toleran dapat dilakukan dengan mutasi fisik. Hasil mutasi tanaman lamtoro yang telah diuji pada media kultur jaringan mampu menghasilkan tanaman toleran terhadap kondisi asam. Melalui penelitian yang dilakukan oleh Manpaki et al (2017) diperoleh mutan tanaman lamtoro tahan asam $\mathrm{pH} 3,4$ secara in vitro. Ketersediaan tanaman Leucaena leucocephala toleran asam dapat dikembangkan pada Indonesia bagian Barat yang memiliki curah hujan yang tinggi dan kondisi tanah yang asam seperti Kalimantan dan Jawa.

Upaya penyediaan bibit yang berkualitas pada tanaman lamtoro dapat dilakukan melalui pembiakan in vitro seperti teknik kultur jaringan. Kultur jaringan merupakan suatu metode yang dilakukan untuk mengisolasi bagian dari tanaman kemudian menumbuhkan eksplan tanaman secara masal dikultur dalam kondisi aseptik (Wattimena et al. 2011). Metode kultur jaringan dapat menghasilkan bibit yang banyak dalam waktu yang relatif cepat (Santoso \& Nursandi, 2004).

Teknik kultur jaringan secara umum terdapat empat tahapan yang meliputi tahap induksi, multiplikasi, pembentukan akar dan aklimatisasi. Tahap aklimatisasi yaitu tahapan adaptasi pada kondisi tempat tumbuh dari lingkungan in vitro ke tempat tumbuh lapangan. Tahap kritis yang dilalui tanaman setelah keluar dari botol kultur memiliki perbedaan kondisi iklim di rumah kaca maupun lapangan. Proses aklimatisasi dapat menentukan hasil akhir keberhasilan teknik kultur jaringan. Handini (2012) menyatakan bahwa kondisi non aseptik dan tidak terkontrol seperti suhu, cahaya serta kelembaban, menyebabkan tanaman harus mampu bertahan hidup dalam kondisi autotrof.

Penelitian ini menggunakan tanaman lamtoro berakar dan tidak berakar yang dikembangkan dari hasil teknik kultur jaringan. Perlakuan yang tepat dan terkontrol pada tanaman pada kultur jaringan akan menentukan tingkat keberhasilan saat aklimatisasi. Penelitian bertujuan untuk melihat respon pertumbuhan selama tahap aklimatisasi pada tanaman lamtoro (Leucaena leucocephala) varietas Tarramba toleran asam dan sifat tumbuh berbeda sehingga diperoleh bibit mutan terbaik.

\section{METODE}

\section{Alat dan Bahan}

Alat yang digunakan dalam penelitian ini yaitu jangka sorong, autoklaf, thermohygrometer, lampu neon dan rak penyimpanan.

Bahan yang digunakan dalam penelitian ini meliputi mutan Leucaena leucocephala varietas Tarramba hasil dari tahap pengakaran kultur jaringan, zeolit, fungisida Dithane M-45, aquadest dan zat pengatur tumbuh IBA dengan konsentrasi 1 ppm .

\section{Prosedur Penelitian \\ Persiapan alat dan bahan}

Tanaman lamtoro varietas Tarramba, hasil kultur jaringan dari tahap pengakaran sebanyak 13 galur yaitu M1 sampai M11 (mutan hasil penambahan hormon IBA 1 ppm), K0 (tanaman kontrol 0 ppm IBA) dan K1 (tanaman kontrol 1 ppm IBA). Lama penyinaran pada Laboratorium Agrostologi diatur menggunakan time programmer selama 12 jam dari pukul 07.00 - 19.00 WIB. Thermohygrometer diletakkan di rak penyimpanan media.

\section{Persiapan media tanam}

Media tanam menggunakan $100 \%$ zeolit. Zeolit dicuci bersih kemudian dimasukkan kedalam plastik tahan panas. Selanjutnya dilakukan sterilisasi menggunakan autoclave dengan suhu $122^{\circ} \mathrm{C}$ selama 60 menit. Media tanam yang sudah disterilisasi dimasukkan kedalam plastik cup sesuai dengan perlakuan yang akan diberikan dan ditandai dengan pemberian label perlakuan. Media tanam diberikan aquadest sebelum dilakukan penanaman planlet lamtoro.

\section{Aklimatisasi}

Tanaman hasil kultur jaringan yang diperoleh dari Laboratorium Agrostologi, Divisi Ilmu dan Teknologi Tumbuhan Pakan dan Pastura, Departemen Ilmu Nutrisi dan Teknologi Pakan, Fakultas Peternakan, IPB University. Tanaman dikeluarkan dari botol kultur menggunakan pinset dan dibersihkan dari media kultur di bawah air yang mengalir. Tanaman kemudian direndam dalam larutan aquades $1 \mathrm{~L}$ dan $1 \mathrm{~g}$ fungisida 'Dithane M-45', kemudian dipindahkan pada bak yang dilapisi tissue. Setelah itu, tanaman dipindahkan pada media tanam dan disiram lalu disungkup menggunakan plastik yang sudah diberikan akuades. Tanaman diletakkan diatas bak dan kemudian dipindahkan pada rak dengan pencahayaan lampu neon yang sudah diatur menggunakan time programmer. Pengamatan dilakukan selama 1 minggu sekali selama 5 minggu setelah tanam (MST) dan penyiraman dilakukan selama 2 hari sekali.

\section{Variabel yang Diamati}

Tingkat viabilitas tanaman. Tingkat viabilitas merupakan jumlah tanaman yang bertahan hidup selama tahap aklimatisasi. Tingkat viabilitas dihitung berdasarkan rumus berikut :

$$
\frac{\sum \text { tanaman yang hidup }}{\sum \text { tanaman yang ditanam }} \times 100 \%
$$


Tinggi tanaman (mm). Pengukuran tinggi tanaman dilakukan dengan menggunakan jangka sorong Caliper $150 \mathrm{~mm}$, pengukuran dimulai dari tanaman yang berada di atas permukaan tanah hingga pucuk tertinggi. Pengukuran dilakukan selama 7 hari sekali hingga 5 minggu setelah tanam (MST).

Jumlah daun. Pengamatan jumlah daun dilakukan selama 5 minggu setelah tanam (MST), pengambilan data selama 7 hari sekali.

\section{Rancangan dan Analisis Data Rancangan percobaan}

Rancangan yang digunakan dalam penelitian ini adalah Rancangan Acak Lengkap (RAL) dengan 11 galur mutan yaitu M1 sampai M11 (mutan toleran asam hasil kultur jaringan penambahan 1 ppm IBA), dan 2 kontrol (lamtoro indukan tanpa penyinaran gamma) yaitu K0 (lamtoro indukan hasil kultur jaringan penambahan 0 ppm IBA), K1 (lamtoro indukan hasil kultur jaringan penambahan 1 ppm IBA). Variabel yang diamati adalah tingkat viabilitas tanaman, tinggi vertikal tanaman dan jumlah daun.

\section{Analisis data}

Data yang diperoleh dari hasil pengamatan dianalisis dengan menggunakan ANOVA. Apabila terdapat perbedaan nyata $(\mathrm{p}<0,05)$ di antara perlakuan maka dilakukan uji lanjut dengan menggunakan uji Tukey (Steel \& Torrie 1993).

\section{HASIL DAN PEMBAHASAN}

\section{Persentase Viabilitas}

Perbedaan kondisi lingkungan in vitro dan in vivo dapat mempengaruhi tingkat viabilitas pada tanaman selama tahap aklimatisasi. Tingkat viabilitas tanaman lamtoro (Leucaena leucocephala) pada tahap aklimatisasi yang dilakukan selama 5 minggu setelah tanam (MST) disajikan pada Tabel 1 .

Tabel 1 menunjukkan tingkat viabilitas tanaman lamtoro (Leucaena leucocephala) pada tahap aklimatisasi

yang dilakukan selama 5 MST menunjukkan bahwa galur tanaman dengan persentase viabilitas tanaman tertinggi selama tahap aklimatisasi 5 MST adalah pada galur mutan M3 dengan nilai $80 \%$, sementara persentase viabilitas tanaman terendah adalah pada galur K0 dengan nilai 26,67\%. Hal ini menunjukkan bahwa tingkat viabilitas tanaman mutan hasil seleksi lebih tinggi daripada K0. Tanaman mutan memiliki tingkat adaptasi yang tinggi terhadap lingkungan sehingga mampu bertahan pada lingkungan in-vitro menuju lingkungan in vivo. Hasil yang didapatkan sejalan dengan Marga (2020) yang menyatakan bahwa mutan tanaman lamtoro pasca irradiasi sinar gamma menghasilkan tanaman yang tahan pada tanah masam kejenuhan almunium tinggi sehingga lebih mampu untuk mempertahankan pertumbuhannya. Galur tanaman yang memiliki tingkat viabilitas yang rendah dikarenakan pembentukan akar belum terbentuk dengan sempurna. Menurut Zulkarnain (2009), sistem perakaran yang cenderung mudah rusak dan tidak
Tabel 1 Persentase viabilitas tanaman lamtoro (Leucaena leucocephala) selama tahap aklimatisasi 5 minggu setelah tanam (MST)

\begin{tabular}{ccc}
\hline Galur Tanaman & Berakar & Tidak Berakar \\
\hline & $\ldots \ldots \ldots \ldots \ldots \ldots \ldots \ldots \ldots \ldots \ldots \ldots \ldots \ldots \ldots \ldots \ldots \ldots \ldots \ldots \ldots$ & \\
\hline K0 & 26,67 & 0 \\
K1 & 40,00 & 0 \\
M1 & 53,33 & 0 \\
M2 & 53,33 & 0 \\
M3 & 80,00 & 0 \\
M4 & 53,33 & 0 \\
M5 & 53,33 & 0 \\
M6 & 40,00 & 0 \\
M7 & 53,33 & 0 \\
M8 & 46,67 & 0 \\
M9 & 66,67 & 0 \\
M10 & 66,67 & 0 \\
M11 & 73,33 &
\end{tabular}

K0 (lamtoro kontrol hasil kultur jaringan 0 ppm IBA), K1 (lamtoro kontrol hasil kultur jaringan 1 ppm IBA). M1-M11 (galur mutan lamtoro toleran asam hasil kultur jaringan 1 ppm IBA)

berfungsi dengan baik akan membuat pertumbuhan tanaman pada kondisi lapang sangat tertekan. Kondisi anatomi tanaman yang belum sempurna menyebabkan rendahnya tingkat tumbuh tanaman dan keberhasilan aklimatisasi.

Tahap aklimatisasi merupakan tahapan yang sangat mempengaruhi keberhasilan kultur jaringan yang merupakan tahapan kritis yang dilalui tanaman sebelum dilepas pada kondisi lapang. Pengamatan suhu yang dilakukan selama penelitian berkisar $26,58^{\circ} \mathrm{C}-30,03^{\circ} \mathrm{C}$. Kisaran suhu pengamatan ini sesuai dengan kondisi lingkungan yang cocok untuk tanaman lamtoro (Leucaena leucocephala) yang berada pada iklim tropis dengan suhu $25^{\circ} \mathrm{C}-30^{\circ} \mathrm{C}$ (Soedjono, 2003). Data kelembaban selama tahap aklimatisasi berkisar antara 74,50\% - 81,82\%. Menurut Yusnita (2010) kelembaban pada kisaran $73,13 \%$ - 78,74\% dapat merangsang penebalan lapisan lilin kutikula dan membuat bibit lebih kuat.

Tinggi rendahnya suhu memiliki pengaruh terhadap tinggi rendahnya kelembaban. Kelembaban yang rendah dapat meningkatkan laju transpirasi sehingga penyerapan air serta zat-zat mineral juga dapat meningkat. Jika kelembaban tinggi, maka laju transpirasi menjadi rendah sehingga rendahnya penyerapan nutrien dapat menghambat pertumbuhan tanaman (Sigit, 2008). Dalam kondisi in vitro, lapisan lilin hampir tidak ditemukan dan stomata daun yang lebih terbuka. Hal tersebut menyebabkan tanaman sangat rentan terhadap kelembaban rendah. Pemberian sungkup bertujuan untuk menjaga kelembaban media tumbuh dan mengendalikan respirasi yang berlebihan sebelum bibit kultur tumbuh dan berkembang secara normal (Damayanti et al. 2007).

\section{Tinggi Vertikal Tanaman}

Hasil pengamatan tinggi tanaman mutan lamtoro pada tahap aklimatisasi dapat dilihat dari rata-rata pertumbuhan tanaman dari Tabel 2. 
Tabel 2. Tinggi vertikal tanaman lamtoro (Leucaena leucocephala) pada tahap aklimatisasi 5 minggu setelah tanam (MST).

\begin{tabular}{|c|c|c|c|c|c|}
\hline \multirow{3}{*}{ Galur } & \multicolumn{5}{|c|}{ Umur (MST) } \\
\hline & 1 & 2 & 3 & 4 & 5 \\
\hline & \multicolumn{5}{|c|}{ 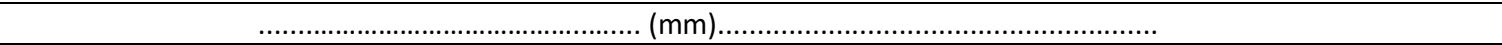 } \\
\hline KO & $31,18 \pm 1,31^{\mathrm{e}}$ & $41,00 \pm 5,22 \mathrm{bc}$ & $47,22 \pm 5,01$ de & $57,22 \pm 5,46$ de & $58,01 \pm 4,14^{f}$ \\
\hline K1 & $30,88 \pm 1,11$ e & $37,48 \pm 6,79 \mathrm{~cd}$ & $42,10 \pm 8,87$ ef & $49,41 \pm 12,86$ ef & $56,28 \pm 16,12^{f}$ \\
\hline M1 & $45,34 \pm 3,59 a b$ & $59,07 \pm 5,33$ a & $70,35 \pm 9,80$ ab & $77,81 \pm 6,73^{b}$ & $81,36 \pm 4,23$ bc \\
\hline M2 & $31,75 \pm 1,23$ e & $42,80 \pm 5,24 b c$ & $55,34 \pm 4,84 \mathrm{~cd}$ & $65,24 \pm 9,22 b c$ & $75,89 \pm 6,68 \mathrm{~cd}$ \\
\hline M3 & $47,78 \pm 2,09$ a & $66,06 \pm 4,89 a$ & $78,62 \pm 8,44^{a}$ & $92,50 \pm 4,87^{a}$ & $100,03 \pm 1,78^{a}$ \\
\hline M4 & $42,37 \pm 1,99 \mathrm{bc}$ & $47,76 \pm 5,17^{b}$ & $53,39 \pm 5,58 \mathrm{~cd}$ & $60,64 \pm 8,21 \mathrm{~cd}$ & $70,50 \pm 7,21 \mathrm{de}$ \\
\hline M5 & $36,49 \pm 1,95^{d}$ & $38,68 \pm 2,68 \mathrm{~cd}$ & $47,75 \pm 5,32$ de & $61,12 \pm 8,54 \mathrm{~cd}$ & $76,20 \pm 5,60 \mathrm{~cd}$ \\
\hline M6 & $31,48 \pm 1,69$ e & $34,23 \pm 2,76$ de & $39,55 \pm 2,42 \mathrm{fg}$ & $52,12 \pm 10,83 \mathrm{de}$ & $61,32 \pm 11,08$ ef \\
\hline M7 & $27,75 \pm 3,01 \mathrm{e}$ & $29,23 \pm 3,23^{f}$ & $34,15 \pm 6,09 \mathrm{~g}$ & $45,11 \pm 6,14^{f}$ & $66,79 \pm 11,97 \mathrm{de}$ \\
\hline M8 & $41,07 \pm 1,78^{c}$ & $43,75 \pm 4,05 \mathrm{bc}$ & $55,81 \pm 11,56 \mathrm{~cd}$ & $65,12 \pm 7,83 \mathrm{bc}$ & $77,42 \pm 6,14 \mathrm{~cd}$ \\
\hline M9 & $39,64 \pm 3,51 \mathrm{~cd}$ & $45,52 \pm 5,19 b c$ & $62,59 \pm 9,21 \mathrm{bc}$ & $79,42 \pm 7,60 \mathrm{ab}$ & $100,55 \pm 7,95^{a}$ \\
\hline M10 & $38,58 \pm 3,20 \mathrm{~cd}$ & $44,18 \pm 6,30 \mathrm{bc}$ & $60,99 \pm 10,61 \mathrm{bc}$ & $73,90 \pm 9,17 \mathrm{bc}$ & $92,21 \pm 10,73 \mathrm{ab}$ \\
\hline M11 & $30,24 \pm 1,77$ e & $32,80 \pm 6,23$ ef & $45,97 \pm 9,71$ ef & $61,76 \pm 9,84 \mathrm{~cd}$ & $87,41 \pm 8,52 a b$ \\
\hline
\end{tabular}

K0 (hasil tanaman kontrol 0 ppm IBA), K1 (hasil tanaman kontrol 1 ppm IBA). M1-M11 (mutan hasil penambahan hormon 1 ppm IBA). Superskrip yang berbeda pada kolom yang sama berbeda nyata $(\mathrm{p}<0,05)$ berdasarkan Uji Tukey.

Tabel 2 menunjukkan nilai rataan tinggi vertikal tanaman tertinggi pada galur mutan M3 dan M9 dengan tinggi diatas $100 \mathrm{~mm}$. Pada minggu pertama hingga minggu keempat galur mutan M3 secara konsisten menunjukkan rataan tinggi hingga mencapai 92,50 $\mathrm{mm}$ dan minggu kelima tertinggi pada galur mutan M9 dengan rataan mencapai 100,55 mm. Hal ini menunjukkan tanaman mutan hasil seleksi memiliki pertambahan tinggi yang lebih baik dibandingkan dengan kontrol.

Tanaman mutan memiliki pertumbuhan yang sudah teradaptasi sebelumnya dalam media kultur jaringan sehingga kemampuan adaptasi yang ditunjukkan mampu berpengaruh terhadap tumbuh kembang tanaman terutama dalam pertambahan tinggi. Pengaruh induksi mutasi berdasarkan Soedjono (2003) dapat menghasilkan tanaman mutan yang memiliki daya tahan yang lebih baik terhadap cekaman biotik maupun abiotik. Variasi genetik pada mutan lamtoro dapat terlihat dari kemampuan untuk tumbuh yang ditunjukkan oleh respon masing-masing galur tanaman, sehingga dapat terlihat bahwa keragaman genetik terbaik dari galur mutan M3 dan M9. Hasil ini disesuai dengan pernyataan Marga (2020) yaitu salah satu cara yang dapat dilakukan untuk meningkatkan keragaman genetik adalah dengan induksi mutasi. Mutasi melalui iradiasi sinar gamma telah memberikan kontribusi nyata terhadap perbaikan tanaman didunia, lebih dari 3600 varietas dari 170 jenis tanaman telah dilepas (IAEA, 2010).

\section{Jumlah Daun}

Pertumbuhan daun merupakan bentuk respon tanaman pada tahap aklimatisasi. Hasil penelitian terhadap pertambahan jumlah daun ditunjukkan pada Tabel 3 . Hasil analisis ragam jumlah daun tanaman menunjukkan interaksi nyata $(\mathrm{p}<0,05)$. Pada minggu pertama sampai dengan minggu ketiga jumlah daun tertinggi pada galur mutan M3 dengan jumlah rata-rata daun 15,33 helai hingga mencapai 24,33 helai pada 5 MST, hal ini menunjukkan bahwa jumlah daun galur mutan M3 memiliki jumlah daun tertinggi dibandingkan dengan galur tanaman yang lainnya. Jumlah daun pada tanaman berhubungan erat dengan kemampuan proses fotosintesis yang berbeda pada setiap galur tanaman. Hal

Tabel 3. Jumlah daun lamtoro (Leucaena leucocephala) teradaptasi asam pada tahap aklimatisasi $5 \mathrm{minggu}$ setelah tanam (MST)

\begin{tabular}{|c|c|c|c|c|c|}
\hline \multirow{3}{*}{ Galur } & \multicolumn{5}{|c|}{ Umur (MST) } \\
\hline & 1 & 2 & 3 & 4 & 5 \\
\hline & \multicolumn{5}{|c|}{ 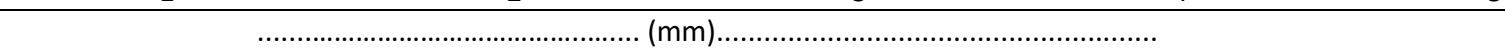 } \\
\hline KO & $8,75 \pm 0,50^{e}$ & $10,00 \pm 0,82 \mathrm{fg}$ & $11,00 \pm 0,82 \mathrm{fg}$ & $13,00 \pm 1,41^{\text {cd }}$ & $13,25 \pm 1,26^{f}$ \\
\hline K1 & $8,50 \pm 0,55^{e}$ & $9,33 \pm 1,21^{\mathrm{g}}$ & $10,00 \pm 1,67 \mathrm{~g}$ & $11,33 \pm 2,80^{d}$ & $14,67 \pm 4,08$ ef \\
\hline M1 & $14,75 \pm 1,16 \mathrm{ab}$ & $16,50 \pm 1,41^{b}$ & $18,13 \pm 1,46$ ab & $18,63 \pm 1,41 a b$ & $19,13 \pm 0,83 \mathrm{~cd}$ \\
\hline M2 & $12,50 \pm 2,00 \mathrm{bc}$ & $13,88 \pm 1,96^{c}$ & $15,25 \pm 1,67$ bc & $16,88 \pm 1,64$ ab & $18,25 \pm 1,67^{\mathrm{cd}}$ \\
\hline M3 & $15,33 \pm 1,23$ & $18,50 \pm 1,98$ a & $19,67 \pm 2,10^{a}$ & $20,83 \pm 1,64$ & $24,33 \pm 0,78^{a}$ \\
\hline M4 & $11,63 \pm 1,19 \mathrm{~cd}$ & $13,00 \pm 1,51 \mathrm{~cd}$ & $15,00 \pm 2,20 b c$ & $17,88 \pm 2,59$ ab & $19,38 \pm 1,85^{c d}$ \\
\hline M5 & $9,25 \pm 0,89$ de & $10,13 \pm 0,83 \mathrm{fg}$ & $10,88 \pm 0,99 \mathrm{fg}$ & $13,38 \pm 1,92 \mathrm{~cd}$ & $18,13 \pm 0,83 \mathrm{~cd}$ \\
\hline M6 & $8,50 \pm 0,84$ e & $8,83 \pm 0,75 \mathrm{~g}$ & $10,00 \pm 1,26 \mathrm{~g}$ & $12,00 \pm 0,63 \mathrm{~d}$ & $14,17 \pm 0,98^{f}$ \\
\hline M7 & $9,50 \pm 1,07$ de & $9,88 \pm 0,83 \mathrm{fg}$ & $11,63 \pm 1,30$ ef & $13,38 \pm 1,69 \mathrm{~cd}$ & $15,75 \pm 2,05 \mathrm{de}$ \\
\hline M8 & $9,29 \pm 0,76$ de & $10,57 \pm 1,13$ ef & $12,71 \pm 1,60$ de & $13,57 \pm 1,62 \mathrm{~cd}$ & $15,14 \pm 1,46$ ef \\
\hline M9 & $11,20 \pm 1,75 \mathrm{~cd}$ & $13,60 \pm 1,90 \mathrm{~cd}$ & $16,60 \pm 2,50 \mathrm{ab}$ & $19,50 \pm 2,64 \mathrm{ab}$ & $23,20 \pm 1,69 a b$ \\
\hline M10 & $9,80 \pm 1,69$ de & $11,20 \pm 1,48$ ef & $13,90 \pm 1,60 \mathrm{~cd}$ & $16,60 \pm 1,71 \mathrm{bc}$ & $20,20 \pm 2,62 b c$ \\
\hline M11 & $10,27 \pm 1,79 \mathrm{~cd}$ & $11,91 \pm 2,39 \mathrm{de}$ & $14,73 \pm 3,07 \mathrm{~cd}$ & $18,09 \pm 4,28 \mathrm{ab}$ & $20,27 \pm 3,69 b c$ \\
\hline
\end{tabular}


ini sejalan dengan penelitian yang dilakukan oleh Zulastri (2020) yang menyatakan bahwa daun merupakan salah satu organ tanaman tempat terjadinya proses fotosintesis.

Respon yang ditunjukkan mutan lamtoro terhadap jumlah daun memiliki perbedaan antara nomor galur tanaman. Berdasarkan pengaruh sifat tumbuh perakaran, respon setiap tanaman sangat bervariasi, hal tersebut berdampak juga pada jumlah daun tanaman. Proses pengakaran memiliki dampak terhadap jumlah daun dikarenakan tanaman berakar mampu menyerap nutrien dengan baik pada media tanam sehingga pertumbuhan dan perkembangan organ tanaman lebih optimal termasuk daun. Hal tersebut sejalan dengan penelitian yang dilakukan Zulastri (2020) yang menyatakan bahwa sifat tumbuh perakaran berpengaruh nyata meningkatkan pertambahan jumlah daun tanaman.

\section{SIMPULAN}

Tanaman Lamtoro (Leucaena leucocephala) hasil kultur jaringan pada tahap aklimatisasi menunjukan galur mutan M3 dan M9 memberikan respon terbaik terhadap tingkat viabilitas tanaman, pertambahan tinggi vertikal dan jumlah daun tanaman.

\section{DAFTAR PUSTAKA}

[IAEA] International Atomic Energy Agency. 2010. Mutant Variety and Genetic Stock Database. Austria (AT): IAEA.

Damayanti D, Sudarsono, Mariska, I \& Herman M. 2007. Regenerasi pepaya melalui kultur in vitro. Jurnal AgroBiogen. 3(2): 49-54.

Handini AS. 2012. Pengaruh paclobutrazol terhadap pertumbuhan anggrek Dendrobium lasianthera pada tahap aklimatisasi [skripsi]. Bogor (ID): Fakultas Pertanian, Institut Pertanian Bogor.

Manpaki SJ, Karti, PDM \& Prihantoro I. 2017. Respon pertumbuhan eksplan tanaman lamtoro (Leucaena leucocephala cv. tarramba) terhadap cekaman kemasaman media dengan level pemberian aluminium melalui kultur jaringan. Jurnal Sain Peternakan Indonesia. 12(1):71-82.

Marga A. 2020. Perakitan tanaman lamtoro (Leucaena leucocephala) terdaptasi tanah masam. [tesis]. Fakultas Peternakan. Bogor (ID) : Institut Pertanian Bogor.

Santoso U \& Nursandi F. 2004. Kultur Jaringan Tanaman. Malang (ID) : UMM Pres.

Sarwono, B. 1987. Pengelompokan Hijauan Makanan Ternak. Jakarta (ID): Trubus

Sigit Y. 2008. Kajian elongasi dan aklimatisasi pada kultu in vitro Aquilaria beccariana van Tiegh. [skripsi]. Bogor (ID) : Fakultas Kehutanan, Institut Pertanian Bogor.

Soedjono S. 2003. Aplikasi mutasi induksi dan variasi somaklonal dalam pemuliaan tanaman. Jurnal Penelitian dan Pengembangan Peetanian 22(2):34-40

Wattimena GA, Wiendi NM, Ansori N, Purwito A. Efendi D, Khumaida N \& Purwoko BS. 2011. Bioteknologi dalam Pemuliaan Tanaman. Bogor (ID): IPB Press.
Yusnita. 2003. Kultur Jaringan: Cara Memperbanyak Tanaman secara Efisien. Jakarta (ID) : Agro Media Pustaka

Yusnita. 2010. Perbanyakan In vitro Tanaman Anggrek. Bandar Lampung (ID) : Universittas Lampung

Zayed MZ, Ahmad FB, Zaki MA, Ho WS \& Pang SL. 2014. The reduction of mimosine content in Leucaena leucocephala (petai belalang) leaves using ethylmethanesulphonate (EMS). Archives of Applied Science Research. 6(4):124-128.

Zulastri R, Karti PDMH \& Mutia R. 2020. Aklimatisasi pada tanaman lamtoro (Leucaena leucocephala) cv. Tarramba pasca irradiasi sinar gamma dan sifat tumbuh yang berbeda. [skripsi]. Bogor (ID) : IPB University.

Zulkarnain. 2009. Kultur Jaringan Tanaman Solusi Perbanyakan Tanaman Budidaya. Jakarta (ID) : Bumi Aksara

Irwan Z. 2020. Kadar zat nutrien daun kelor (Moringa oleifera) berdasarkan metode pengeringan. Jurnal Kesehatan Manarang. 6 (1): $69-77$.

Koten BB, Soetrisno RD, Ngadiyono N, \& Soewignyo B. 2014. Perubahan nilai nutrient tanaman sorgum (Sorghum bicolor (L.) Moench) varietas local rote sebagai hijauan pakan ruminansia pada berbagai umur panen dan dosis pupuk urea. Pastura. 3 (2) : 55-60.

Kumalasari NR, Wicaksono GP, \& Abdullah L. 2017. Plant growth pattern, forage yield, and quality of Indigofera zollingeriana influenced by row spacing. Media Peternakan. 40 (1):14-19. doi: https://doi.org/10.5398/medpet.2017.40.1.14.

Laka M \&Wangge ESA. 2018. Uji kadar protein pada beberapa varietas umbi ubi kayu (Manihot esculenta Crantz) yang dihasilkan di Desa Randotonda, Kecamatan Ende, Kabupaten Ende. AGRICA. 11 (1) : 43-50.

Masganti, Anwar K, \& Susanti MA. 2017. Potensi dan pemanfaatan lahan gambut dangkal untuk pertanian. Jurnal Sumberdaya Lahan 11 (1): 43-52.

Masganti, Wahyunto, Dariah A, Nurhayati, \& Yusuf R. 2014 Karakteristik dan potensi pemanfaatan lahan gambut terdegradasi di Provinsi Riau. Jurnal Sumberdaya Lahan. 8 (1): 59-66.

Savitri MV, Sudarwati H, \& Hermanto. 2013. Pengaruh umur pemotongan terhadap produktivitas gamal (Gliricidia sepium) Jurnal Ilmu-Ilmu Peternakan. 23 (2): 25-35.

Setiyaningrum E, Kaca IN, \& Suwitari NKE. 2018. Pengaruh umur pemotongan terhadap produksi dan kualitas nutrisi tanaman indigofera (Indigofera sp). Gema Agro. 23 (1): 59-62. doi:10.22225/ga.23.1.660.59-62.

Sriagtula R, Karti PDM.H, Abdullah L, Supriyanto, \& Astuti DA. 2017. Nutrient changes and in vitro digestibility in generative stage of M10-BMR sorghum mutant lines. Media Peternakan. 40 (2):111117.

Tantalo S, Liman, \& Fathul F. 2019. Efek umur pemangkasan indigofera (Indigofera zollingeriana) pada musim kemarau terhadap kadar neutral detergent fibre dan acid detergent fibre. Jurnal Ilmiah Peternakan Terpadu. 7(2): 241-246.

Tarigan A, Abdullah L, Ginting SP, \& Permana IG. 2010. Produksi dan komposisi nutrisi serta kecernaan in-vitro Indigofera $s p$. pada interval dan tinggi pemotongan berbeda. Jurnal Ilmu Ternak dan Veteriner. 15 (2): 188-195.

Vinyard JR, Hall JB, Sprinkle JE, \& Chibisa GE. 2018. Effects of maturity at harvest on the nutritive value and ruminal digestion of Eragrostis tef (cv. Moxie) when fed to beef cattle. Journal of Animal Science. 96 (8) :3420-3432. doi:10.1093/jas/sky202.

Yanuartono, Purnamaningsih H, Indarjulianto S, Nururrozi A, Raharjo S, \& Haribowo N. 2019. Perlakuan biologis dengan memanfaatkan fungi untuk meningkatkan kualitas pakan ternak asal hasil samping pertanian. Jurnal Peternakan Sriwijaya. 8 (2): 18-34.

Zhao CX, He MR, Wang ZL, Wang YF, Lin Q. 2009. Effects of different water availability at post-anthesis stage on grain nutrition and quality in strong-gluten winter wheat. Comptes Rendus Biologies. 332 (8): 759-764. doi: 10.1016/j.crvi.2009.03.003 